\title{
The Levys of New Orleans: An Old Myth and a New Problem
}

RAVEN I. McDAVID, JR. and

\author{
SAMUEL R. LEVIN
}

\begin{abstract}
A
S EVERY SERIOUS STUDENT in the field is aware, the study of names is full of amusing incidents, tall tales, blind alleys, pitfalls and hoaxes. It is not uncommon for a hoax to take in a serious scholar; but it is rare that one took in H. L. Mencken (no mean fabricator of hoaxes himself, when he chose), and through him was filtered into the academic profession and even into the sacred halls of business. But only the assumption of such a hoax, perpetrated by a serious onomastician, can satisfactorily explain Mencken's statements about the prominence of Levy as a New Orleans surname in the light of what appear to be irrefutable facts.

Mencken's first mention of the prominence of the Levy tribe in New Orleans comes in the fourth edition of The American Language (1936), p. 477: "In New Orleans [Smith] is followed, rather inexplicably, by Levy, with Miller and Williams following." The same account appears in Supplement Two (1948), p. 401, without the earlier skeptical qualification: "In New Orleans [the five most common surnames] are Smith, Levy, Miller, Williams and Brown."

Among the simple-minded but necessary chores involved in updating The American Language for the 1963 edition was determining whether or not the surname-rankings for certain American cities were still in 1963 what Mencken had stated they were in 1936 and 1948. Since no large-scale study of these rankings by cities has recently been published, and since many of the larger cities no longer publish directories of residents, it was decided to resort to
\end{abstract}


the alphabetical telephone directories, with full awareness that in some communities certain ethnic strains might not be adequately represented. ${ }^{1}$

By luck, New Orleans was the first city so investigated. But the results ran counter to expectations. Levy, far from being the second most common surname, was not even twenty-second; subsequent checking, in fact, places it no higher than a tie with Bell for thirtyninth; and it may be even lower, since only those names expected to rank high were systematically checked, though names shown to rank high by inspection of the directory were normally caught, checked and ranked. With only half a page in the listings, Levy would have been ignored but for Mencken's statement. The old statement was replaced by the current ranking; a caveat about the myth was inserted in a footnote, and attention was directed to other cities and other problems.

The next stage of the investigation, after the manuscript of the new edition was ready for the press, came with an examination of the collection of city directories in the Newberry Library, to determine whether Levy had ever in fact held the ranking attributed to it by Mencken in 1936 and 1948. Since Rodriguez is now the sixth most common surname in the Bronx, where it was hardly known two generations ago, similar changes might have occurred in New Orleans. But again, a sampling of directories ${ }^{2}$ from 1871 to 1949

1 Telephone directories are more representative of the general population than they were a generation or more ago, when they were rarely found in homes of the poor; among some groups, however, such as Negroes and Latin-Americans, they are not as common even now as among the native-born whites.

For access to directories, in the winter of 1960-61, RIM expresses his thanks to the reference library of the Illinois Bell Telephone Company, and to Don Thompson, at that time in charge of the Bell system account at N. W. Ayer \& Son. For the use of the New Orleans directories, in the summer of 1962, SRL expresses his appreciation of the courtesies extended by the staff of the Newberry Library, for which he was then a consultant in linguistic bibliography. References to the 1963 edition of The American Language, and to subsequent investigations of Mencken's sources, indicate the activity of RIM.

2 The surname Levy does not occur in the earliest New Orleans directory (1805), which lists only some 800 surnames, mostly French. Among American surnames most familiar today, Martin (a not uncommon French surname) led with 7, followed by Brown and Jones ( 4 each), then Robinson, White and Williams (two each). There were but single examples of Smith, Johnson, Davis, Lewis, Moore, Thomas and Wilson. 
failed to support the myth: from nineteenth place in 1871, Levy rose to eighteenth in 1900 and sixteenth in 1910, then declined to eighteenth in 1920, twenty-fourth in 1928, twenty-fifth in 1932 and at best twenty-sixth in 1949 .

The evidence examined, the reason for Mencken's apparent lapse must be accounted for. One must remember that Levy has two common American pronunciations, /liyviy/ and /leviy/; the last, probably the more common one in the South a generation ago, is homonymous with levee, a significant feature of the New Orleans landscape and economy. In fact, there was a well-worn vaudeville gag of the 1920s - also often used as a filler in small-town newspapers - which ran more or less this way:

Mrs. Murphy: And where have you been, Mrs. O'Leary? I haven't seen you for a month.

Mrs. O'Leary: Faith, and it's the Mister and me that went to visit his brother in New Orleans.

Mrs. Murphy: New Orleans, is it? That's sure a fine city. And what did you think of the levees?

Mrs. O'Leary: Sure, and I tried to phone 'em three times, but they were out of town, and the Cohens with 'em.

As an aficionado of burlesque, Mencken certainly knew this story. And his reputation as a purveyor of hoaxes to the generality would incline a reader to suspect that here was another, based on an elementary pun. In fact, for those who see the spectre of antisemitism behind every joke involving a Jewish surname, this would seem to be fresh evidence as to the lamentable prejudices to which Mencken is alleged to have been addicted. When the research staff of the New Orleans Public Library failed to disclose any local basis for the Levy story before 1936, there seemed no alternative to laying its origin at Mencken's doorstep. ${ }^{3}$

However, the qualifying phrase, "rather inexplicably," in the 1936 edition suggested that Mencken's sources be examined first. And at the end of the paragraph, in that edition, in which the ranking by cities is given, there is a reference to an article by Howard F. Barker, "the foremost authority on American

${ }^{3}$ Mr. Albert Goldstein, of the New Orleans Times-Picayune, gallantly sought the missing evidence, both through his own files and through the New Orleans Public Library. 
surnames." An examination of the passage cited discloses the statement: "New Orleans gives honors to Smith, 61; Levy, 48; Miller, 38; Williams, 35, followed closely by the triumvirate, Brown, Jones and Johnson." Barker then goes on to say: "The numbers in the above sampling of urban conditions ${ }^{5}$ are simply indexes to display the internal ratios in the number of listings in directories." He further states (after his extrapolations for the United States as a whole, but apparently intending to give authority to all his reckonings): "My methods of measurement and calculation have been such that I am satisfied that the foregoing name-usages are accurate, particularly in their ratios to each other, to within one or two percent, and that my reckoning on any name of consequence seldom errs by five percent." Yet despite Barker's reasoning, the evidence from the New Orleans directories as we have examined them shows that Levy has never been a third as common locally as Williams, nor has Miller ever approached the frequency of Johnson or Brown. Well might Mencken comment, "Rather inexplicably."

Mencken is thus exonerated both of responsibility for the error, and of any wilful "antisemitism" that the error might imply. The statement is Barker's, taken in good faith by Mencken. Now we must ask, in turn, of Barker: how could a serious scholar perpetrate such a misstatement? and what motive might there be behind it?

Here we are on more speculative ground than we were when dealing with Mencken, at least for the time being, since Barker nowhere gives specific sources and those that he gives - "directories" - on examination contradict his statement. But it is true that elsewhere Barker has seemed overly preoccupied with surname-changes by American Jews. ${ }^{6}$ Could this preoccupation have led him to distort, wilfully and pointlessly, the evidence from a major American city? Or could he or his associates, mechanically checking other New Orleans directories than simple lists of residents, dictate levee and have it taken down as Levy? In either instance - deliberate distortion or carelessness - the facts about New Orleans make it necessary to look skeptically at Barker's other statements, about

4 "Our Leading Surnames," American Speech, 1.471 (June, 1926).

5 Barker had, of course, cited ranks and ratios for several communities.

6 As, for instance, in "Names in is," American Speech, 2.316-18 (Apr., 1927). 
other surnames and other communities. Nor does the circle of influence stop here. At least one manual for organizing office files has swallowed the Levy myth and perpetuated it, by advising the designers of filing systems for New Orleans offices to allow extra room for Levy as one of the ten most common local surnames. ${ }^{7}$

But more important is the lesson for scholars. If Mencken erred in taking at face value a statement by "the leading authority on American surnames," it is unlikely that many of us, in a similar position, would have gone behind the statement to look for the evidence, even if we had had the time. It impresses us, once more, with the burden of a serious scholar - to verify all references, especially those of which he is sure. ${ }^{8}$ Yet how could Mencken have verified Barker's statement when Barker himself gave no citation to which Mencken - or anyone else - could turn?

Finally, my own implication. The hunt for the true story of the Levys has disclosed to me a half-dozen typographical errors and other minor lapses in my transmission of the Mencken tradition. Following Mencken's example, I have confessed them to my chaplain, called them to the attention of my editors, and hoped for the best. But such personal embarrassment is a small price to pay for the knowledge that here, as elsewhere, Mencken simply took the best sources available and reported the facts as he had found them stated.

\section{University of Chicago: RIM}

\section{Hunter College: SRL}

7 Margaret K. Odell and Earl P. Strong, Records Management and Filing Operations, New York and London: McGraw-Hill Book Company, Inc., 1947, p. 193. No authority is given for the alleged frequency of Levy.

8 This was particularly emphasized by my mentor, Allan H. Gilbert, of Duke University. Its importance was brought out several times in the winter of 1940 , when as his research assistant I was verifying references and citations for his Literary Criticism: Plato to Dryden. In particular, a routine check of line-references to the Odyssey disclosed a misreading that had been perpetuated by three centuries of translators of the Aristotelian Poetics: by misreading, unaccountably, a linebeginning accusative $\mu \varepsilon$ as if it had been the nominative $\varepsilon \gamma \omega \dot{\omega}$, they had as it were caused Polyphemus to describe himself rather than Odysseus as a person weak and small and of no account. 


\section{Appendix: Ranking of New Orleans Surnames}

1960

1. Smith

2. Williams

3. Johnson

4. Jones

5. Brown

6. Jackson

7. Davis

8. Miller

9. Martin

10. Thomas

11. Landry

12. LeBlanc

13. Lewis

14. Wilson

15. Green

16. White

17. Boudreaux

18. Harris

19. Taylor

20. Thompson

21. Adams

22. Robinson

23. Moore

24. Anderson

25. Bourgeois

26. Walker

27. King

28. Allen

29. Butler

30. Phillips

31. Murphy

32. Turner

33. Hall

34. Evans

35. James

36. Kelly

37. Roberts

38. Nelson

39. Bell

40. Levy
1871

1. Smith

2. Johnson

3. Williams

4. Brown

5. Miller

6. Jones

7. Wilson

8. Jackson

9. Martin

10. Davis

11. White

12. Thomas

13. Green

14. Taylor

15. Moore

16. Thompson

17. Lewis

18. Anderson

19. Levy

20. Robinson

21. Harris

22. Allen

1900

1. Smith

2. Johnson

3. Williams

4. Brown

5. Jones

6. Miller

7. Davis

8. Wilson

9. Jackson

10. Thomas

11. White

12. Thompson

13. Lewis

14. Taylor

15. Martin

16. Moore

17. Harris
18. Levy

19. Robinson

20. Green

21. Anderson

1910

1. Smith

2. Johnson

3. Williams

4. Brown

5. Miller

6. Jones

7. Davis

8. Jackson

9. Thomas

10. Harris

11. Lewis

12. White

13. Moore

14. Wilson

15. Martin

16. Levy

17. Thompson

18. Taylor

19. Anderson

20. Robinson

21. Green

22. Landry

23. Hall

24. LeBlanc

1920

1. Smith

2. Williams

3. Johnson

4. Brown

5. Miller

6. Jones

7. Davis

8. Jackson

9. Martin

10. Thomas

11. Wilson 
12. Thompson

13. White

14. Lewis

15. Harris

16. Moore

17. Taylor

18. Levy

19. Landry

20. Green

21. Anderson

22. LeBlanc

23. Robinson

24. Hall

1928

1. Smith

2. Williams

3. Johnson

4. Jones

5. Brown

6. Jackson

7. Miller

8. Davis

9. Thomas

10. Martin

11. Lewis

12. White

13. Landry

14. Harris

15. Wilson

16. Taylor

17. Moore
18. LeBlanc

19. Green

20. Anderson

21. Robinson

22. Thompson

23. Boudreaux

24. Levy

25. Allen

26. Hall

1932

1. Williams

2. Smith

3. Johnson

4. Jones

5. Brown

6. Davis

7. Jackson

8. Miller

9. Thomas

10. Lewis

11. Martin

12. Wilson

13. White

14. Harris

15. Landry

16. Green

17. Moore

18. Taylor

19. Thompson

20. Robinson

21. LeBlanc

22. Anderson
23. Allen

24. Boudreaux

25. Levy

26. Hall

1949

1. Williams

2. Smith

3. Johnson

4. Jones

5. Brown

6. Jackson

7. Davis

8. Miller

9. Thomas

10. Lewis

11. Wilson

12. Landry

13. Le Blanc

14. Martin

15. White

16. Harris

17. Boudreaux

18. Taylor

19. Anderson

20. Green

21. Robinson

22. Moore

23. Thompson

24. Allen

25. Hall

26. Levy

27. Baker 